\title{
Recent Developments in Rh Heterogeneous Catalysts
}

\author{
János Kiss ${ }^{1,2, *(\mathbb{D})}$ and Imre Kovács ${ }^{3}$ (D) \\ 1 MTA-SZTE Reaction Kinetics and Surface Chemistry Research Group, University of Szeged, \\ Rerrich Béla Square 1, 6720 Szeged, Hungary \\ 2 Interdisciplinary Excellence Centre, Department of Applied and Environmental Chemistry, \\ University of Szeged, Rerrich Béla Square 1, 6720 Szeged, Hungary \\ 3 Institute of Technology, University of Dunaújváros, Táncsics M. u. 1/A, 2401 Dunaújváros, Hungary; \\ kovacsimidr@gmail.com \\ * Correspondence: jkiss@chem.u-szeged.hu
}

Citation: Kiss, J.; Kovács, I. Recent Developments in Rh Heterogeneous Catalysts. Catalysts 2021, 11, 416. https://doi.org/10.3390/catal11040416

Received: 12 March 2021

Accepted: 15 March 2021

Published: 25 March 2021

Publisher's Note: MDPI stays neutral with regard to jurisdictional claims in published maps and institutional affiliations.

Copyright: (c) 2021 by the authors. Licensee MDPI, Basel, Switzerland. This article is an open access article distributed under the terms and conditions of the Creative Commons Attribution (CC BY) license (https:// creativecommons.org/licenses/by/ $4.0 /)$.
Rh-based catalysts successfully catalyze bond making and bond breaking reactions in most cases. Rhodium (Rh) has been one of the focuses of catalyst research from industrial and environmental points of view from the middle of seventies. This ascertainment is valid even nowadays, which is reflected in this Special Issue, too. $\mathrm{Rh}$ is one of the most important components of three-way catalysts [1,2]. A three-way catalyst oxidizes exhaust gas pollutants - both hydrocarbons ( $\mathrm{HC})$ and carbon monoxide $(\mathrm{CO})$ - and reduces nitrogen oxides $\left(\mathrm{NO}_{\mathrm{x}}\right)$ into harmless components, such as water $\left(\mathrm{H}_{2} \mathrm{O}\right)$, nitrogen $\left(\mathrm{N}_{2}\right)$ and carbon dioxide $\left(\mathrm{CO}_{2}\right)$. Therefore, the mechanism of the reaction of $\mathrm{NO}$ with $\mathrm{CO}$ was extensively studied on oxide supported Rh catalysts, and it was established that isocyanate (NCO) surface complex is a real reaction intermediate [3-6]. The $\mathrm{CO}$ and $\mathrm{CO}_{2}$ hydrogenation with hydrogen and methane is also an important issue from the past to the present. These reactions may result in reducing the poisoning and in producing compounds that are more valuable. Significant attention has been paid to the relations between catalytic activity, reaction mechanism and intermediates [7-11]. Furthermore, it was revealed that supported $\mathrm{Rh}$ was a promising catalyst for carrying out the transformation of oxo-hydrocarbons (alcohols, aldehydes) producing hydrogen as a potential fuel. It is an important conclusion that Rh plays an important role in the dissociation of carbon-carbon bonds $[12,13]$.

Despite the high cost of rhodium metal, its superior catalytic properties at low temperature still make it indispensable to understand the interaction between the metal and the support, to check the surface compounds formed during the reaction, and to show the elementary steps of the reaction, and as additives appear to be unavoidable for the development of an effective and stable catalyst. Considering this economic demand, several important attempts are made to reduce the expenses. These efforts are reflected in the recent studies and in this Special Issue, too. Firstly, the amount and the size of the Rh catalyst can be minimized with the optimal preparation circumstances; secondly, the applied second adatom may increase the catalytic efficiency of the Rh nanoparticles. Finally, the new generation support materials for Rh may increase the catalytic performance in many cases. Following these efforts, methods are developed for the deposition of Rh, which results in nanosized distribution of the metal on the supports; the thermal stability and reactivity of $\mathrm{Rh}$ nanoclusters were studied, especially on $\mathrm{CeO}_{2}$ and on an ultrathin alumina film $[14,15]$. The infrared study of carbon monoxide adsorption greatly helps in the mapping of morphology and oxidation states of Rh nanoparticles prepared on supports [16]. Very recently, it turned out, in several cases, that the adatom, similar to cobalt, significantly enhanced the $\mathrm{Rh}$ activity in the steam reforming of ethanol. The catalytic activity of $0.1 \% \mathrm{Rh}+2 \%$ Co on ceria exceeded the activity of $5 \% \mathrm{Rh} / \mathrm{CeO}_{2}$ catalysts [17]. A similar promoting effect was observed in the dry reforming of methane using alumina supported Rh-Co bimetallic catalysts [18]. The physical-chemical properties and the morphology of the support may determine the nature of the interaction between rhodium and the support. It has been 
recently demonstrated, by several examples in the literature, including the papers in the present Special Issue, that different nanostructured supports, such as titania, may modify the activity and selectivity of rhodium in $\mathrm{CO}_{2}$ hydrogenation, water-gas shift reactions and in ethanol transformation $[19,20]$. Furthermore, it was demonstrated in two reviews that different oxide supports changed not only the conversion, but the selectivity and the mechanism of $\mathrm{CO}_{2}$ hydrogenation and the dry reforming of methane when Rh-based catalysts were used [21,22]. The numerical simulation of methane and other reforming alkanes was carried out over the $\mathrm{Rh} / \mathrm{Al}_{2} \mathrm{O}_{3}$ catalyst in stagnation flows, emphasizing the importance of the impact of internal and external mass transfer [23]. The study of catalytic reactions of hydrogenation, including hydrodeoxygenation, was extended to several aromatics in the gas phase [24] and in liquid medium on Rh-based catalysts [25].

Very recently, it was demonstrated that titanate nanotubes influenced the reaction path in $\mathrm{CO}_{2}$ hydrogenation in the presence of sodium. A significant amount of formic acid $(\mathrm{HCOOH})$ was produced [26]. Several studies were published on the importance of formic acid recently [27-29]. It turned out that $\mathrm{HCOOH}$ is an important chemical for renewable energy systems and $\mathrm{H}_{2}$ can be applied for fuel cell vehicles; formic acid is a good candidate as a $\mathrm{H}_{2}$ storage compound. The importance of $\mathrm{HCOOH}$ for fuel cell application can nowadays be demonstrated by an increased number of patents. Due to this direction, the investigations of catalytic decomposition and surface chemistry of $\mathrm{HCOOH}$ on different catalysts, including $\mathrm{Rh}$, are renewed [30,31].

In conclusion, this Special Issue clearly shows the importance of the optimization of size and chemical environment of Rh nanoparticles. It is demonstrated that the type of the support changes the conversion and the selectivity of the studied Rh catalyzed reactions. Finally, we would like to remember that Prof. Frigyes Solymosi was one of the great scientists who (with his research group) successfully took part in the research of Rh-catalyzed reactions from the early seventies up to very recently. Unfortunately, he passed away when we just started structuring this Special Issue. His 90th birthday would have fallen in March this year.

We would like to thank all the authors of this Special Issue for their contributions. The reviewers are gratefully acknowledged. We are honored to be the Guest Editors of this Special Issue published in the Catalysts journal. We are also grateful to the Editor-in-Chief, Prof. Dr. Adam F. Lee, and all the staff of the Catalysts Editorial Office, in particular to the Managing Editor, Adela Liao.

Author Contributions: The authors contributed to write the paper in equal extent. All authors have read and agreed to the published version of the manuscript.

Funding: This research received no external funding.

Conflicts of Interest: The authors declare no conflict of interest.

\section{References}

1. Hegedus, L.L.; Summers, J.C.; Schlatter, J.C.; Baron, K. Poison-resistant catalysts for the simultaneous control of hydrocarbon, carbon monoxide, and nitrogen oxide emissions. J. Catal. 1979, 56, 321-335. [CrossRef]

2. Yao, H.C.; Yu, Y.C. Ceria in automotive exhaust catalysts: I. Oxygen storage. J. Catal. 1984, 86, 254-265. [CrossRef]

3. Unland, M.I. Isocyanate intermediates in the reaction of NO and CO over noble metal catalysts. J. Catal. 1973, $31,459-465$. [CrossRef]

4. Solymosi, F.; Sárkány, J. An Infrared Study of the Surface Interaction between $\mathrm{NO}$ and $\mathrm{CO}$ on $\mathrm{Rh} / \mathrm{Al}_{2} \mathrm{O}_{3}$ Catalysts. Appl. Surf. Sci. 1979, 3, 68-82. [CrossRef]

5. Kiss, J.; Solymosi, F. Surface Behaviour of NCO Species on Rh(111) and Polycrystalline Rh. Surface. Surf. Sci. 1983, 135, 243-260. [CrossRef]

6. Kiss, J.; Solymosi, F. The Effect of Adsorbed Oxygen on the Stability of NCO on Rh(111) Studied by Reflection Absorption Infrared Spectroscopy. J. Catal. 1998, 179, 277-282. [CrossRef]

7. Sexton, B.A.; Somorjai, G.A. The hydrogenation of $\mathrm{CO}$ and $\mathrm{CO} 2$ over polycrystalline rhodium: Correlation of surface composition, kinetics and product distributions. J. Catal. 1977, 46, 167-189. [CrossRef]

8. Fisher, I.A.; Bell, A.T. A Comparative Study of $\mathrm{CO}$ and $\mathrm{CO}_{2}$ Hydrogenation over Rh/SiO 2 . J. Catal. 1996, 162, 54-65. [CrossRef] 
9. Solymosi, F.; Erdőhelyi, A. Hydrogenation of $\mathrm{CO}_{2}$ to $\mathrm{CH}_{4}$ over alumina -supported noble metal. J. Mol. Catal. 1980, 8, 471-474. [CrossRef]

10. Solymosi, F.; Kutsán, G.; Erdőhelyi, A. Catalytic reaction of $\mathrm{CH}_{4}$ with $\mathrm{CO}_{2}$ over alumina-supported Pt-metals. Catal. Lett. 1991, 11, 149-156. [CrossRef]

11. Solymosi, F.; Kiss, J.; Kovács, I. Adsorption and Decomposition of HCOOH on Potassium Promoted Rh(111) Surfaces. J. Phys. Chem. 1988, 92, 796-803. [CrossRef]

12. Mavrikakis, M.; Barteau, A.A. Oxygenate reaction pathways on transition metal surfaces. J. Mol. Catal. Chem. 1998, 131, 135-147. [CrossRef]

13. Sheng, P.Y.; Yee, A.; Bowmaker, G.A.; Idriss, H. $\mathrm{H}_{2}$ Production from Ethanol over Rh-Pt/ $\mathrm{CeO}_{2}$ Catalysts: The Role of Rh for the Efficient Dissociation of the Carbon-Carbon Bond. J. Catal. 2002, 208, 393-403. [CrossRef]

14. Varga, E.; Pusztai, P.; Oszkó, A.; Baán, K.; Erdőhelyi, A.; Kónya, Z.; Kiss, J. Stability and Temperature-Induced Agglomeration of Rh nanoparticles Supported on $\mathrm{CeO}_{2}$. Langmuir 2016, 32, 2761-2770. [CrossRef]

15. Liao, Z.-H.; Hsu, P.-W.; Hung, T.-C.; Liao, G.-J.; Chern, Z.-Y.; Lai, Y.-L.; Yu, L.-C.; Hsu, Y.-J.; Wang, J.-H.; Chen, P.; et al. Investigation of Thermal Stability and Reactivity of Rh Nanoclusters on an Ultrathin Alumina Film. Catalysts $2019,9,971$. [CrossRef]

16. Idriss, H.; Llorca, J. Low Temperature Infrared Study of Carbon Monoxide Adsorption on Rh/CeO 2 . Catalysts 2019, 9, 598. [CrossRef]

17. Ferencz, Z.; Erdőhelyi, A.; Baán, K.; Oszkó, A.; Óvári, L.; Kónya, Z.; Papp, C.; Steinrück, H.-P.; Kiss, J. Effects of Support and Rh Additive on Co-Based Catalysts in the Ethanol Steam Reforming Reaction. ACS Catal. 2014, 4, 1205-1218. [CrossRef]

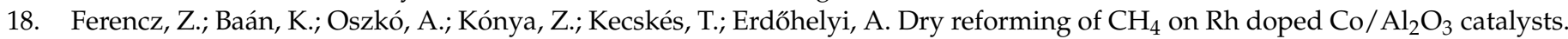
Catal. Today 2014, 228, 123-130. [CrossRef]

19. Kukovecz, Á.; Kordás, K.; Kiss, J.; Kónya, Z. Atomic Scale Characterization and Surface Chemistry of Metal Modified Titanate Nanotubes and Nanowires. Surf. Sci. Rep. 2016, 71, 473-546. [CrossRef]

20. Kiss, J.; Sápi, A.; Tóth, M.; Kukovecz, Á.; Kónya, Z. Rh-induced Support Transformation and Rh Incorporation in Titanate Structures and Their Influence on Catalytic Activity. Catalysts 2020, 10, 212. [CrossRef]

21. Erdőhelyi, A. Hydrogenation of carbon Dioxide on Supported Rh Catalysts. Catalysts 2020, 10, 155. [CrossRef]

22. Erdőhelyi, A. Catalytic Reaction of Carbon Dioxide with Methane on Supported Noble Metal. Catalysts 2021, 11, 159. [CrossRef]

23. Karadeniz, H.; Karakaya, C.; Tischer, S.; Deutschmann, O. Numerical Simulation of Methane and Propane Reforming Over a Porous $\mathrm{Rh} / \mathrm{Al}_{2} \mathrm{O}_{3}$ Catalyst in Stagnation-Flows: Impact of Internal and External Mass Transfer Limitations on Species Profiles. Catalysts 2020, 10, 915. [CrossRef]

24. Kirkwood, K.; Jackson, S.D. Hydrogenation and Hydrodeoxygenation of Oxygen-Substituted Aromatics over Rh/silica: Catechol, Resorcinol and Hydroquinone. Catalysts 2020, 10, 584. [CrossRef]

25. Rufete-Beneite, M.; Roman-Martinez, M.C. Unraveling Toluene Conversion during the Liquid Phase Hydrogenation of Cyclohexene (in Toluene) with Rh Hybrid Catalysts. Catalysts 2019, 9, 973. [CrossRef]

26. Ruiz-Gracia, J.R.; Fierro-Gonzales, J.C.; Handy, B.E.; Hinojosa-Reyes, L.; De Haro Del Rio, D.A.; Luicio, C.J.; Valle Cervantes, S.; Flores-Escamilla, G.A. An In Situ Infrared Study of $\mathrm{CO}_{2}$ Hydrogenation to Formic Acid by Using Rhodium Supported on Titanate Nanotubes as Catalysts. Chem. Sel. 2019, 4, 4206-4216.

27. Moret, S.; Dyson, P.J.; Laurenczy, G. Direct synthesis of formic acid from carbon dioxide by hydrogenation in acidic media. Nat. Commun. 2014, 5, 4017. [CrossRef]

28. Fink, C.; Laurenczy, G. A precious catalyst: Rhodium-catalyzed formic acid dehydrogenation in water. Eur. J. Inorg. Chem. 2019, 19, 2381-2387. [CrossRef]

29. Yu, Z.; An, X.; Kurnia, I.; Yoshida, A.; Yang, X.; Hao, X.; Abudula, A.; Fang, Y.; Guan, G. Full Spectrum Decomposition of Formic Acid over $\gamma-\mathrm{Mo}_{2} \mathrm{~N}$ Based Catalysts: From Dehydration to Dehydrogenation. ACS Catal. 2020, 10, 5353-5361. [CrossRef]

30. Halasi, G.; Schubert, G.; Solymosi, F. Photodecomposition of formic acid on N-doped and metal-modified TiO ${ }_{2}$ : Production of CO-free $\mathrm{H}_{2}$. J. Phys. Chem. C 2012, 116, 15396-15405. [CrossRef]

31. Kovács, I.; Kiss, J.; Kónya, Z. The Potassium-Induced Decomposition Pathway of HCOOH on Rh(111). Catalysts 2020, 10, 675. [CrossRef] 